This item was submitted to Loughborough's Research Repository by the author.

Items in Figshare are protected by copyright, with all rights reserved, unless otherwise indicated.

\title{
Demystifying the Euro in European financial centre relations: London and
} Frankfurt, 2000-2001

PLEASE CITE THE PUBLISHED VERSION

http://dx.doi.org/10.1080/14782800500180268

PUBLISHER

(C) Taylor \& Francis (Routledge)

VERSION

AM (Accepted Manuscript)

LICENCE

CC BY-NC-ND 4.0

\section{REPOSITORY RECORD}

Beaverstock, Jonathan V., Michael Hoyler, Kathryn Pain, and Peter J. Taylor. 2019. "Demystifying the Euro in European Financial Centre Relations: London and Frankfurt, 2000-2001". figshare.

https://hdl.handle.net/2134/4921. 
This item was submitted to Loughborough's Institutional Repository (https://dspace.lboro.ac.uk/) by the author and is made available under the following Creative Commons Licence conditions.

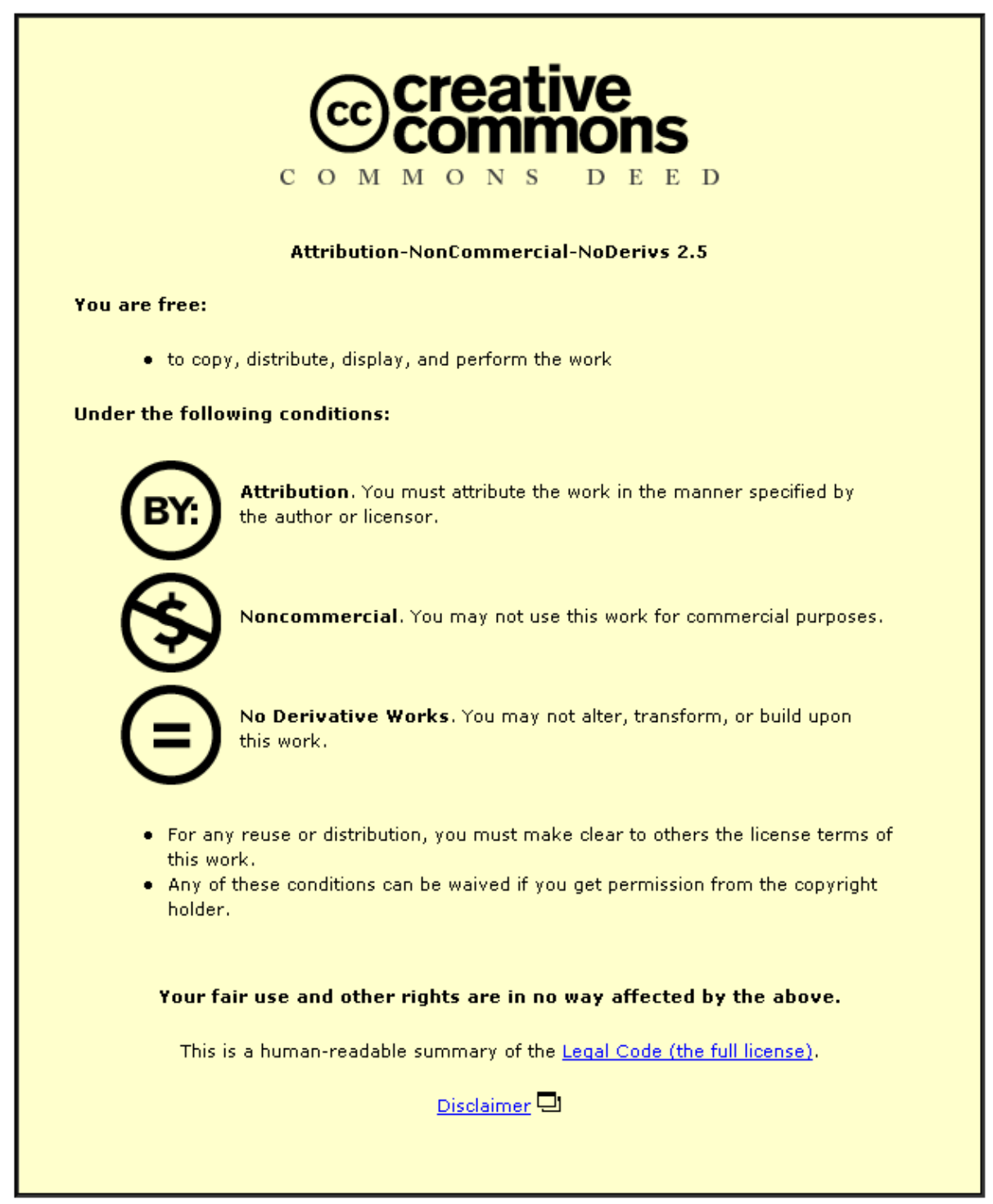

For the full text of this licence, please go to: http://creativecommons.org/licenses/by-nc-nd/2.5/ 
This article was published in Journal of Contemporary European Studies 13(2) (2005), pp. 143-157. doi:10.1080/14782800500180268

The definite version is available at http://www.informaworld.com/

(C) Taylor \& Francis

\title{
Demystifying the Euro in European Financial Centre Relations: London and Frankfurt, 2000-2001
}

\author{
Jonathan V. Beaverstock*, Michael Hoyler*, Kathryn Pain**, Peter J. Taylor* \\ * Department of Geography, Loughborough University, UK \\ ** Institute of Community Studies, London, UK
}

\begin{abstract}
The introduction of the Single European Currency, the Euro, put London and Frankfurt's position as European financial centres under the spotlight at the beginning of the Twenty-First Century. Many commentators suggested that London being outside 'Euroland' would begin to leak capital, labour and prowess to Frankfurt as the German city out-muscled London as the preeminent European financial centre for the next Century. In the British and German financial national press the discourse was one of competition and rivalry with predicted winners and losers depending on whether one stood in London or Frankfurt. The London-Frankfurt rivalry is a microcosm of traditional world city research, which in this paper is turned on its head. In-depth research with financial institutions and stakeholders in each city pre-Euro indicated that London's relationship with Frankfurt is based more on cooperation and strong network relations between the two cities than competition. In effect, the cities are bound together by firm and regulatory ties and networks, cross-border mobility and working practices and complementary, relational roles in Europe's architecture of financial centres. Accordingly, we conclude in this paper that London will always be Europe's premier financial centre because of its scale and relationships with New York and Tokyo, but equally note that Frankfurt and London are co-dependent on each other in a Europe of relational cities.
\end{abstract}

\footnotetext{
${ }^{1}$ Funded by The Anglo-German Foundation for the Study of Industrial Society.
} 


\section{Introduction}

'How long will these towers still be standing in Frankfurt?' ('Wie lange stehen diese Türme noch in Frankfurt?') was a question provocatively asked in a fullpage advertisement, run by the Financial Times Deutschland in November 2000 to announce a series of articles on the future of the city. Following the recent establishment of the European Central Bank in Frankfurt and the introduction of the euro as legal currency in $11 \mathrm{EU}$ member states, this question came as a symbolic blow to Germany's financial centre. However, the image of a threatened international financial centre was but one in a series of intense speculations about the future of Europe's financial landscape after the creation of European Economic and Monetary Union (EMU). At the end of the 1990s, London and Frankfurt were widely regarded as the two major European financial centres. While London had long been one of the world's global cities (Sassen, 1991) and the leading fully integrated financial hub in Europe, Frankfurt had more recently been seen to move from national to European scale (Bördlein, 1999; Schamp, 1999; Harrschar-Ehrnborg, 2002; Keil and Lieser, 1992; Felsenstein et al., 2002), building on its post-WWII ascendancy to become Germany's main banking centre (Holtfrerich, 1999; Grote, 2004). The language of the media was clearly couched in confrontational terms: Would the advent of the euro currency, with the UK outside, enable Frankfurt to successfully challenge London as Europe's premier international financial centre, or would London's dominance lead to the eventual downfall of the aspiring contender? In this paper we address this question in three parts. First, we briefly discuss Frankfurt and London's position in the network of world cities. Second, we provide a detailed analysis of Frankfurt's relations with London at the onset of the euro, as seen through the lens of key London and Frankfurt finance and business communities, who purport the networking relations that bind the two cities together. Finally, we report that while London will continue to cast a long shadow over its European world city neighbours, complementary network relations have so far strengthened both London and Frankfurt's positions as international financial centres. The research design was an interview survey with 48 CEOs in leading transnational banks, accounting and consulting firms, legal practices and advertising agencies, and 26 senior 
executives of regulatory, trade/professional and government agencies. Interviews were conducted in both London and Frankfurt and shed light on: the firms' adjustment to the euro with respect to cross-border investments, clients and markets in Frankfurt and London; and how they were responding to the euro in the context of wider global relations (see Beaverstock et al., 2001).

\section{Frankfurt and London's Inter-City Relations}

\section{Frankfurt and London in the World City Hierarchy}

Studies of world cities have been dominated by Friedmann's (1986) 'world city hierarchy', who ranked cities according to the way they orchestrated production and markets in the world economy. In Friedmann's hierarchy, Frankfurt was designated as a 'core country' 'primary world city', below, in rank order, London, Paris and Rotterdam, but above Zurich. This and similar rankings were based upon an analysis of attribute data, for example the number of TNC headquarters. Later, Friedmann (1995: 35) noted that Frankfurt was the 'premier German global city', designated as a 'multinational articulation' for western Europe (Table 1). Frankfurt was described as a city which coordinated capital in western Europe, primarily through its position as a banking centre, but was not ranked alongside London, New York and Tokyo, which sat atop his hierarchy of thirty world cities (Table 1). Inspecting Friedmann's (1995) positioning of European world cities shows that in the case of Germany there is no German 'national articulation', instead Munich and Düsseldorf-CologneEssen-Dortmund (Rhine-Ruhr) have all been designated at the 'subnational/regional' level.

Frankfurt, therefore, never makes it into the top tier in Friedmann's work: London is consistently shown as Europe's only world city at the apex. The importance of London in comparison to Frankfurt is supported by 26 basic indicators of financial prowess, where London/UK is found to be leading Frankfurt/Germany on 23 of them (Table 2). But it is important to understand that such figures do not indicate that London is above Frankfurt in a new urban hierarchy. These are attribute measures that show London to be a far larger 
financial centre; they say nothing about how the two cities are networked. Attributes provide measures of size that allow cities to be ranked but should not be confused with hierarchical processes (Taylor, 1997). For the latter to be shown there needs to be direction from above impinging on the actions below. This requires measures of relations between cities, not simple ranking by size. Thus Table 2 shows London to be more important as a world city, a finding consistent with Friedmann's 'world city hierarchy' but does not confirm the existence of the latter. In fact, it is not at all clear in what sense 'London' directs 'Frankfurt' as a hierarchical process (Beaverstock et al., 1999, Taylor and Hoyler, 2000).

\section{Frankfurt and London in a World City Network}

As world cities operate as bases for transnational economic activity they are inevitably tied together through multiple connectivities within a new space of flows that traverses what Castells (2000) calls the old 'space of places'. We interpreted world cities as nodes that define a world city network (Beaverstock et al., 2002, Taylor, 2004). In order to investigate Frankfurt's potentially changing position via London since the introduction of the euro, it is necessary to study the relations between the two cities within this wider conceptual framework.

The world city network is not like typical networks where the nodes (usually members of a group) are the actors that produce the network. It is advanced producer service firms (e.g., accounting, advertising, banking, consulting, legal services) that are the principal creators of the world city network through their global locational strategies for servicing clients. These firms have become the dominant internationally organised activities in the world economy because they must operate as cross-border networks to provide 'seamless' services for their corporate customers anywhere in the world (Dicken, 2003). To do this effectively, and compete successfully with market competitors, their city-based offices must function as co-operative cells within the global organisation. In this way, these myriad office networks constitute a world city network with information, knowledge, ideas, plans, intelligence and 
strategy linking cities together across the globe. There is a very important corollary from replacing the hierarchical model by a network one. Hierarchies are premised upon processes of competition, in contrast, networks imply processes of co-operation - without fundamental mutuality any network will cease to function and collapse (Powell, 1990). It follows that in a world city network, cities share a synergy of roles that are complementary within the operation of the overall network. Cities, therefore, do not themselves compete with each other: the competition is between the firms operating in various global service markets (Beaverstock et al., 2002).

Guided by this interlocking network model, data have been collected for 100 global service firms across 315 cities (Taylor et al., 2002). Using basic network analysis techniques, measures of interlock connectivities between cities have been computed from this data to provide global network connectivity values (Taylor et al., 2002). The global network connectivity of a city indicates its relational importance as a node within the world city network: the top 15 cities ranked by this measure are shown in the left columns of Table 3 . This relational measure confirms the importance of London compared to Frankfurt shown above using attribute measures (Tables 1 and 2): London is ranked top and Frankfurt ranked a relatively lowly 14th. In addition, this relational measurement approach is quite flexible. If the connectivity is measured for banking/finance firms only (shown in the right columns of Table 3), Frankfurt rises appreciably to 7th position i.e. in comparison to London, Frankfurt is more narrowly an international financial centre rather than a rounded global service centre.

\section{Frankfurt and London in a Europe of Cities}

At the end of the 1990s, Frankfurt was widely regarded as being at a critical point in its development as a world city. Firstly, the German government's success in securing the location of the European Central Bank, was seen as promoting Frankfurt's position, since in future monetary policy for 11 (now 12) countries would be controlled from there. Secondly, the concurrent demise of LIFFE and the success of Deutsche Terminbörse in the international futures 
market suggested that technological developments were allowing business to slip away from London. Thirdly, with the advent of the euro, trade and professional reports predicted that Frankfurt would become the city where international banks and other producer services (e.g., accountancy, management consulting, law and advertising) would congregate in future to access an expanding continental European market.

Together these changes were expected to significantly raise Frankfurt's profile in relation to London. Could Frankfurt emerge from the shadow of London to take over as premier business service hub in Europe? Financial press coverage in both cities depicted a fierce rivalry. In the British Financial Times the relationship was described as 'a bitter war for supremacy' or 'a battle between London and Frankfurt', while the German Frankfurter Allgemeine Zeitung talked of Frankfurt's 'powerplay' and London as a 'threat'. This was the way the Frankfurt-London relationship was widely portrayed in Europe (Beaverstock et al., 2001: 6-8). However, primary research based on in-depth interviews with financial and business firms, regulators and local government, conducted in 2000 and 2001, has debunked the powerful media representations of 'conflict': London and Frankfurt's position in a world city network is characterised much more by mutuality and inter-dependency than the aggressive headlines suggest.

\section{Demystifying the Euro in European Financial Centre Relations}

Interviews in both cities addressed the financial press contention that the introduction of the euro and the location of the European Central Bank in Frankfurt would change relations between the cities. The research focused on the premise that London would begin to 'leak' financial prowess, firms, employment and market share, as Frankfurt re-positioned itself as the new (and expanded) European financial centre. Findings across all sectors in both cities were highly consistent: the euro would not trigger disinvestment from London to Frankfurt. All interviewees noted that the global business environment and financial market conditions took precedence over the (European) regional euro currency in determining relations between London and Frankfurt, and concluded 
that Frankfurt's recent development as a financial and business services centre had not been detrimental to business in London. Interviewees stressed the lack of importance attached to the euro: '...the fact that the euro has not been introduced in England has changed nothing in relation to the leading position of London, including the euro-business'; and, '... one doesn't make a decision on locating an operation on the basis of a currency, whether it's sterling or the euro or the DM, it's really not behind a decision to locate an office anywhere in Europe. You do that because of the business locally or internationally. A variety of factors play a much greater role than the currency itself'.

Interviewees in both cities stressed the difference in relative size of the cities. London was regarded as being in a different league to Frankfurt, '...the premier European financial centre on most measures that you want to use' and '...the only city in Europe to do true international business'. London's size was seen as critical to its role as the focal point for international business in Europe while Frankfurt was seen as a very important financial base for continental Europe. In sum, London was regarded as the unassailable world city and international financial centre in Europe. London was viewed as being more liberal and open to foreign investment than Frankfurt - with greater critical mass, depth of infrastructure, skills, creativity, employment flexibility and the international business language. But, equally, respondents noted that London had to remain guarded and not become complacent. Frankfurt was strengthening its position relative to London because of greater innovation, deregulation, liberalisation and integration of markets evident in the capture of some parts of the European and international financial services market (e.g., International Bond Market). Equally, Frankfurt was cheaper to do business than London with a fast and efficient transportational system and global airlinks to other international financial centres. Recent investigations in both Frankfurt (Spahn et al., 2002) and London (HM Treasury, 2003) confirm these findings on the minor role of the euro as an agent of locational change. If the new currency and Frankfurt's associated role were not determinants of change, what were? A series of cross-cutting relational networks was found to shape the global and local connections of capital, labour and enterprise between London and Frankfurt in a world city network. 


\section{Making the Network}

Relations between London and Frankfurt were found to be fundamentally linked to global and local market conditions. The dynamic nature of customer servicing relationships, labour markets, business products and technologies results in a complexity of contradictory drivers and tensions that firms must continuously manage in order to remain competitive. Demand for cross-border services gives firms the incentive to expand their geographical market coverage and many firms insist that a failure to do so would seriously damage their ability to win business and remain competitive in their market as in the case of London law firms who identified an increasing need for a physical presence in the German legal market. The underlying tensions shaping the Frankfurt-London relational networks can be conceptualised as organisational-specific, knowledge-specific, operational-specific and locational-specific.

(a) Organisational-specific. The perceived need for critical mass to compete effectively on a global scale and to stretch business across geographical space in cross-border markets is associated with organisational specificities. In producer services, growth between cities ultimately leads to organisational concentration (via mergers and acquisitions) and to organisational rationalisation to stay economically competitive. At the same time, firms stressed the need to focus on core functions remaining in London and Frankfurt (while outsourcing or offshoring back-office tasks to peripheral locations in Asia) and ensuring that product delivery remained flexible within different markets. In the future, the pressures for increased industry representation at the top end of the services sectors and at the bottom 'niche' market end are likely to drive continuing restructuring of business relations between London and Frankfurt.

(b) Knowledge-specific. The knowledge products of producer services are embodied in their skilled people, and highly qualified labour is the key asset for firms. Competition between firms within tight labour markets and for increased market share has led to flexible specialisation (e.g., in financial market trading) but also diversification (e.g., accounting offering consulting), so firms can differentiate their services from their competitors. In accountancy, interviewees 
noted that 'everybody's looking now for more and more specialism'; and, 'we're migrating skills [from London] to other European countries, particularly Frankfurt'. In legal services, the need to build specialist teams has led to 'whole teams being poached' in both Frankfurt and London. In management consulting, intense competition for skills between the two cities was leading to the formation of new business models, strategic alliances and market diversification.

(c) Operational-specific. At the same time, operational decentralisation and local interpretation is a priority to build customer relationships and engage with local markets. Lawyers noted that, '... if you get to number one or two in the UK, you can't pretend to be a global firm if you're offering a number eight operation in Germany, or France, or Italy. You've got to be in the top three everywhere'. A German banker in London commented, '...you can't just sit here and expect everyone to come ... increasingly you have to put your resources onto the ground because you want to be close to the customer ... because there's a lot of competition out there'. Both de-centralising and centralising tendencies can be seen in operational networks. On the one hand, ICT developments allow functions to be located almost anywhere in the world, yet there are also pressures to control risk and reduce costs by centralising functions. In the late 1990s, German and continental European banks were increasingly putting key global functions into London, as one banker noted: '...you have to have a big critical mass in each location to achieve focus on organisational goals ... significant hidden non-monetary costs ... turn into monetary costs in decentralising ... operational risks limit how much division of labour you can have'.

(d) Locational-specific. Economic competitiveness brings a need for proximity. Proximity in London and Frankfurt is critical to contemporary service business. The presence of skilled labour markets and the agglomeration economies associated with face-to-face contact and knowledge transfer in global cities are also strong drivers for locational concentration. As a banker observed, '...l see more concentration coming in here [London] all the time and less and less in other places ... over time you could see a hell of a lot more trading taking place 
in this environment'. Another banker commented, '...the need for human contact is incredible, it's still a very, very strong issue ... that's an overriding factor. Despite all the potential the internet offers, there will still be a very, very strong desire by management to keep everything co-located'. A lawyer noted, '...sitting in London l've got both local and global' and an accountant believed, '...the issues about London and therefore whether face-to-face meeting/conferencing are important, in my view that hasn't changed and will not change'.

Attempts to resolve these various specificities produce dynamic flows within and between producer service networks, and play a crucial role in constructing and reconstructing network relationships between the cities. However, interview discussions highlighted the fact that wider forms of interweaving networks beyond the discussed office linkages contribute significantly to the shaping of London-Frankfurt relations.

Interweaving Networks

Research revealed four interweaving wider relational networks that produce London-Frankfurt relations in a European network of cities.

(a) Knowledge Networks. 'Local' flows of knowledge between London and Frankfurt are highly interconnected with wider inter-city network flows. Potentially, knowledge can be made available anywhere in the world through a network: '...you can do it from almost anywhere and it's only some of the old regulatory structures ... that are ... keeping the physical' (Banking, London). Important drivers of such networks are (i) the movement of skills between cities; knowledge is being transferred from London to Frankfurt and vice-versa: 'you have to ... bring the resources to wherever they're needed' and 'people from London are being sent to Frankfurt to develop the skills of people there' (Accountancy, London); and (ii) ICT is allowing the formation of innovative spatial relations between firms and markets and is an important future medium for firms to engage with local markets globally. Local market knowledge and 
close client relationships are increasingly important in a competitive market causing firms to feel the need for a physical presence in Frankfurt. As one firm noted, '... one of the advantages of a network ... [is] ... if you have to do something in another country you can adapt it ... [but] ... you'll have to have the people there who can smell and feel and know that and who can then realise it' (Advertising, Frankfurt). But technology offers economies of scale, 'a bifurcation $\ldots$ an execution platform and a research platform that interfaces with customers with little human touch' (Banking, London). These developments open up possibilities of engaging with markets through a smaller local physical presence (Grote et al., 2002, Laulajainen, 2001).

However, the research did indicate that business flows could bypass Frankfurt as European service firm headquarters and knowledge concentration remained focused in London. As to the future business strategies for banking in Frankfurt, interviewees commented on the requirement to be flexible: '...there has to be a real business reason ... there would have to be a real demand to operate a specific operation out of Frankfurt' (UK Bank); ' ... we kept our service functions there [Frankfurt] on the ground and invested in them' (UK Bank); '...we have a presence in Frankfurt to reflect the current role of Frankfurt in the equity markets ... our options are open with regard to Frankfurt at the moment but the concentration of investment presently is elsewhere [London]' (Continental European Bank). Scale of presence in Frankfurt is likely to be adjusted to suit market needs. European banks use various familiar front shop brand names to collect business but the handling of those business transactions is done in London for added value, 'because that's an efficient place to conduct business' (German Bank) and not all German banks will require a substantial physical presence in Frankfurt.

(b) Cultural Networks. Labour is at the fulcrum of this argument. The location of the workforce has become more important than the location of customers, and where skilled people want to live is a critical labour market and office locational determinant. Highly-skilled lifestyle conscious labour of all nationalities wished to live in London, and even key decision-makers have personal (as well as corporate) motivations regarding where they want to work and live. This highlights the importance of the cities as places of consumption: '... with modern 
technology ... it doesn't matter whether [markets] are in Frankfurt or in London or even Timbuctoo ... people have to live somewhere ... you could imagine the relative importance of financial centres being dictated by quite different things from where's the most liquid market, because the liquidity can flow from anywhere - where's the most pleasant to live, theatres, restaurants and all sorts of secondary issues' (Management Consulting, London).

While London has long been regarded as a cosmopolitan city in the fast lane, Frankfurt lacks 'city buzz'. Ambitious people were said to want to work in London, not Frankfurt. The difficulty of recruiting people in Frankfurt was emphasised in both cities: '... the quality of people I have recruited has become better, but it is arduous. If we can't find people in Germany, we try it internationally but it involves higher costs to get people to move to Frankfurt and there is the language problem' (Law, Frankfurt). Moreover, '...the English, Americans or French are not very keen to come to Germany, that's almost nonexistent' (Law, Frankfurt). Attitudes of those based in London to Frankfurt as a place to live were generally negative. Frankfurt was regarded as 'boring' and 'dead from seven or eight o'clock at night' (Law, London). A management consultant in London claimed that even Germans used to living in London, if asked to move to Frankfurt, 'think it's like being banished to the third world'. Frankfurt-based German respondents, however, showed more positive personal attitudes to the experience of living in Frankfurt.

In essence, London's strength in cultural flows was its diversity. Diversity of cultures and languages is necessary to engage with local markets everywhere from a global city hub and these are available in London. In investment banking, London offices are internationally staffed to incorporate multiple ethnicities in an increasingly 'less defined' world: 'Part of the supporting infrastructure is ... the cosmopolitan nature of London as a city ... firms can access any language they need from all the different communities that are actually present in London ... it's about the ease of doing business'.

(c) Corporate Networks. More corporate power is concentrated in London than Frankfurt due to the UK's history of global connections and relationship with US capital in the financial sector of the world economy. Economies of scale suggest that more global leadership positions of financial firms are located in London 
than in Frankfurt with implications for decision-making and global influence. A newly elected European CEO in one international management consulting firm would almost certainly have to move to London; '...this, rightly or wrongly is where the European leadership sits ... if he wanted to change the European location of course he could do that but it's a bit of an effort, there's a little bit of infrastructure!' Frankfurt was described in both cities as a service centre for the German and European market held back by a lack of skills and restrictive regulation. In addition, Frankfurt's position as one of a number of important German business centres was seen as detrimental to its development relative to London: 'Big business is taken away from Frankfurt and is being done elsewhere' ... 'the decision centre for many things is London and not Frankfurt' (Law, Frankfurt); '[For European banks] this is the village where they meet all their competitors and their financiers' (Institution, London); 'I don't think I could point you to a case where anyone has said - ah we can do this in Frankfurt but we can't do it here ... I don't remember anyone who has said ... what we're going to do is beef up our Frankfurt operations and transfer stuff from London to Frankfurt' (Institution, London).

In contrast, London was identified as an international hub and club. The fact that London is favoured by Americans, particularly US investment banks, was seen as 'absolutely critical' to London's position: 'The American banks are at the heart of it ... they have a lot less attachment to Frankfurt' (Institution, London). English as the international business language, London's openness and merchant heritage are important and lead to a critical mass of skills and knowledge. London was described as 'An ever-shifting club ... a hub with all of those skills both local and cross-border all around me'; 'London is so easy as a global hub - it's a great advantage if you're trying to be a global financial city and you're actually in a global city ... there's genuinely global ownership of London' (Non-European Bank). London was seen as providing an infrastructure for transnational business creating scale and critical mass that would not otherwise be present: 'Very few companies in the City of London are owned in this country, or capitalised in this country ... they're mainly American or European owned now [but] the decisions are still being made here' (Law, London). The volume and strength of business flows was seen as 'hard to dislodge' (Institution, London). 
(d) Governance Networks. The regulatory context was a critical determinant of cross-border business flows and there are important differences between Frankfurt and London. For London there is a strong emphasis on maintaining balanced regulation while for Frankfurt there is a greater focus on control and internal growth. As one official noted, '...the infrastructure of the market is all privately owned in one way or another ... is that a disadvantage or does that just reflect the nature of the market place these days ... London will do better ... if you're prepared to be open to new competitors ... we don't try to bias things in one direction or another' (Institution, London). In both cities research indicated that Frankfurt (i.e. Germany) needed to 'open up' and deregulate and come into line with international business practice to increase its international business competitiveness in relation to London and the USA. European regulatory change and progress towards the single market could encourage reform within Germany to Frankfurt's advantage as a world city. Enlargement, less regulated labour markets, corporate re-structuring, increasing demand for producer services and the impact of Anglo-Saxon business practice were seen to increase Germany's power and this could benefit Frankfurt in relation to London. Harmonisation of accounting standards and growth in European and German equity markets were predicted to provide deep pools of capital which would present an opportunity for Frankfurt's growth in a European network of cities.

Moreover, cross-border governance is an issue for London. Continuing progress towards a single European market was seen as important for London. Ensuring that the UK has equal access to the Single Market if it remains outside EMU and that EU directives are consistently implemented in each member state were key London concerns. Institutional conflicts of interest are damaging to cross-border business suggesting a need for co-operation across administrative boundaries. In Germany, conflicting interests arise from the decentralised structure of public and private governance and the separation of Frankfurt as a financial centre from the political capital (Blotevogel, 2000). In the UK, more focused governance benefits London but institutional conflicts of interest are perceived as holding back London's growth. 


\section{Discussion and Conclusions}

This paper has used a major economic event, EMU, to investigate world city network relations between Frankfurt and London. Such an approach goes against the grain of almost all previous world city research (Friedmann, 1986, 1995; Sassen, 1991) and studies of international financial centres (Lee and Schmidt-Marwede, 1993; Porteous, 1999), which have been deeply embedded in the city-competition discourse spawned from comparative, attributive data analyses. From this relational study of Frankfurt and London at the outset of EMU, we offer three major conclusions. First, in spite of the introduction of the Single European currency and the location of the European Central Bank in Frankfurt, London remains the favoured European global service business hub. All the available evidence suggests that international business flows continue to be focused on London leaving Frankfurt in its shade. The key factors shaping relations between the cities can be pinpointed from the interweaving networks we have identified:

- History - London's depth of infrastructure and critical mass of knowledge, skills, languages and power are key business location factors.

- Regulation - London remains an 'open' city for business and a global markets location with favourable regulation, taxation and employment policies.

- Agglomeration and scale economies - London has the highest international flows of capital, knowledge and skills in Europe.

- Labour market and talent - London has a deep transnational skilled and specialised labour market with diversity of languages and cultures required by international business.

- City culture - In 'people-driven' business, London is the preferred city to live and this is critical to its choice as a hub for international business, particularly by the leading global economy, the United States.

Second, we argue that the scale of London's competitive advantage over Frankfurt is not necessarily damaging to Frankfurt in the European space of 
flows. London does not win at the expense of Frankfurt because both are integral parts of a wider world city network. Our research suggests that London's concentration of skills and experience in a single location within Europe was seen as a benefit to business in Frankfurt. Skills are flowing to Frankfurt from London. Frankfurt is close to an expanding market and has strong technology and infrastructure. Frankfurt's growing connections with London are seen as essential to the development of international business in the city and Frankfurt is increasing its importance as a 'gateway city' from London to continental European markets. Third, our research reveals that London-Frankfurt connections are more important than boundaries in the space of inter-city business service flows. Increasing city interdependencies are being brought about by inter-firm competition in cross-border markets supporting the contention that inter-city relations can only be properly understood within the context of a world city network (Beaverstock et al., 2002). London's superior strength of global network connectivity does not seem to challenge or be threatened by relations with Frankfurt - so far the growth of both cities has been boosted. Frankfurt has prospered by being within both similar and different webs of connections to London - the cities have distinctive, complementary roles within a Europe of cities.

\section{Acknowledgements}

Funded by the Anglo-German Foundation for the Study of Industrial Society. 


\section{References}

Beaverstock. J.V., Doel, M.A., Hubbard, P.J. and Taylor, P.J. (2002) Attending to the world: competition, cooperation and connectivity in the world city network, Global Networks, 2(2), pp. 111-132.

Beaverstock, J.V., Hoyler, M., Pain, K. and Taylor, P.J. (2001) Comparing London and Frankfurt as World Cities: A Relational Study of Contemporary Urban Change (London: Anglo-German Foundation for the Study of Industrial Society) Available at http://www.agf.org.uk/pubs/pdfs/1290web.pdf.

Beaverstock, J.V., Smith, R.G. and Taylor, P.J. (1999) A roster of world cities, Cities, 16(6), pp. 445-458.

Blotevogel, H.H. (2000) Gibt es in Deutschland Metropolen? Die Entwicklung des deutschen Städtesystems und das Raumordnungskonzept der 'Europäischen Metropolregionen', in D. Matejovski (Ed.) Metropolen: Laboratorien der Moderne, pp. 179-208 (Frankfurt am Main: Campus).

Bördlein, R. (1999) Finanzdienstleistungen in Frankfurt am Main. Ein europäisches Finanzzentrum zwischen Kontinuität und Umbruch, Berichte zur deutschen Landeskunde, 73(1), pp. 67-93.

Castells, M. (2000) The Rise of the Network Society, 2nd ed. (Oxford: Blackwell).

Dicken, P. (2003) Global Shift: Reshaping the Global Economic Map in the 21st Century, 4th ed. (London: Sage).

Felsenstein, D., Schamp, E.W. and Shachar, A. (Eds.) (2002) Emerging Nodes in the Global Economy: Frankfurt and Tel Aviv Compared (Dordrecht: Kluwer).

Friedmann, J. (1986) The world city hypothesis, Development and Change, 17, pp. 69-83.

Friedmann, J. (1995) Where we stand: a decade of world city research, in P.L. Knox and P.J. Taylor (Eds.) World Cities in a World System, pp. 21-47 (Cambridge: Cambridge University Press).

Grote, M.H. (2004) Die Entwicklung des Finanzplatzes Frankfurt: eine evolutionsökonomische Untersuchung (Berlin: Duncker \& Humblot). 
Grote, M.H., Lo, V. and Harrschar-Ehrnborg, S. (2002) A value chain approach to financial centres - The case of Frankfurt, Tijdschrift voor Economische en Sociale Geografie, 93(4), pp. 412-423.

Harrschar-Ehrnborg, S. (2002) Finanzplatzstrukturen in Europa: die Entstehung und Entwicklung von Finanzzentren (Frankfurt am Main: Lang).

HM Treasury (2003) The Location of Financial Activity and the Euro (London: HMSO).

Holtfrerich, C.-L. (1999) Finanzplatz Frankfurt. Von der mittelalterlichen Messestadt zum europäischen Bankenzentrum (München: Beck).

International Financial Services London (2001) International Financial Markets in the UK (November 2001) (London: IFSL).

International Financial Services London (2002) International Financial Markets in the UK (May 2002) (London: IFSL).

Keil, R. and Lieser, P. (1992) Frankfurt: global city - local politics, in M.P. Smith (Ed.) After Modernism: Global Restructuring and the Changing Boundaries of City Life, pp. 39-69 (New Brunswick, NJ.: Transaction Publishers).

Laulajainen, R. (2001) End of geography at exchanges? Zeitschrift für Wirtschaftsgeographie, 45(1), pp. 1-14.

Lee, R. and Schmidt-Marwede, U. (1993) Interurban competition? Financial centres and the geography of financial production, International Journal of Urban and Regional Research, 17(3), pp. 492-515.

Porteous, D. (1999) The development of financial centres: location, information externalities and path dependency, in R. Martin (Ed.) Money and the Space Economy, pp. 96-115 (Chichester: Wiley).

Powell, W.W. (1990) Neither market nor hierarchy: network forms of organization, Research in Organizational Behavior, 12, pp. 295-336.

Sassen, S. (1991) The Global City: New York, London, Tokyo (Princeton: Princeton University Press).

Schamp, E.W. (1999) The system of German financial centres at the crossroads. From national to European scale, in E. Wever (Ed.) Cities in Perspective: Economy, Planning and Environment, pp. 83-98 (Assen: Van Gorcum). 
Spahn, P.B., van den Busch, U. et al. (2002) Position und Entwicklungsperspektiven des Finanzplatzes Frankfurt (Wiesbaden: FEHReport No. 645).

Taylor, P.J. (1997) Hierarchical tendencies amongst world cities: a global research proposal, Cities, 14(6), pp. 323-332.

Taylor, P.J. (2004) World City Network: A Global Urban Analysis (London: Routledge).

Taylor, P.J. and Catalano, G. (2002) World city network formation in a space of flows, in A. Mayr, M. Meurer and J. Vogt (Eds.) Stadt und Region: Dynamik von Lebenswelten, pp. 68-76 (Leipzig: Deutsche Gesellschaft für Geographie).

Taylor, P.J., Catalano, G. and Walker, D.R.F. (2002) Measurement of the world city network, Urban Studies, 39(13), pp. 2367-2376.

Taylor, P.J. and Hoyler, M. (2000) The spatial order of European cities under conditions of contemporary globalization, Tijdschrift voor Economische en Sociale Geografie, 91(2), pp. 176-189. 
Table 1. Friedmann's 'spatial articulations': 30 world cities

1 Global financial articulations

$\wedge$ London * A (also national articulation)

$\wedge$ New York $A$

$\wedge^{\wedge}$ Tokyo* A (also multinational articulation: SE Asia)

$2 \wedge$ Multinational articulations

^ Miami C (Caribbean, Latin America)

$\wedge$ Los Angeles A (Pacific Rim)

$\wedge$ Frankfurt C (western Europe)

$\wedge$ Amsterdam C or Randstad B Singapore* C (SE Asia)

3 Important national articulations (1989 GDP $>\$ 200$ billion)

$\wedge$ Paris* B

$\wedge$ Zurich C Madrid $^{\star} \mathrm{C}$

Mexico City* A

São Paulo A

Seoul* $A$

$\wedge$ Sydney B

4 Subnational/regional articulations

Osaka-Kobe (Kansai region) B

^ San Francisco C

$\wedge$ Seattle $C$

$\wedge$ Houston $C$

$\wedge$ Chicago $B$

$\wedge$ Boston C

$\wedge$ Vancouver $C$

$\wedge$ Toronto C Montreal C Hong Kong (Pearl River delta) B

$\wedge$ Milano C

Lyon C

Barcelona C

^ Munich C

$\wedge^{\wedge}$ Düsseldorf-Cologne-Essen-Dortmund (Rhine-Ruhr region) B

Population (1980s): (A) 10-20 million; (B) 5-10 million; (C) 1-5 million.

* National capital

$\wedge$ Major immigration target

Source: Friedmann (1995: 24) 
Table 2. London/Frankfurt: Key financial market and locational statistics, 19992001

\begin{tabular}{|c|c|c|c|c|c|}
\hline \multicolumn{6}{|c|}{ (1) Foreign equities, $2000^{i}$} \\
\hline & $\begin{array}{l}\text { Turnover } \\
\text { Ebn }\end{array}$ & $\begin{array}{l}\% \text { of world } \\
\text { turnover }\end{array}$ & $\begin{array}{l}\text { No. of } \\
\text { foreign } \\
\text { companies } \\
\text { listed }\end{array}$ & $\%$ of listings & Global Rank \\
\hline London & 2669 & 48 & 448 & 15 & 2 \\
\hline Frankfurt & 321 & 6 & 245 & 8 & 5 \\
\hline Totals & 5526 & 100 & 1938 & 100 & \\
\hline \multicolumn{6}{|c|}{ (2) International bond market, 2001ii (by nationality of issuer) } \\
\hline & \multicolumn{2}{|c|}{ Value (\$bn) } & \multicolumn{2}{|c|}{$\%$ share } & Global Rank \\
\hline UK & \multicolumn{2}{|l|}{64} & \multicolumn{2}{|l|}{6.0} & 5 \\
\hline Germany & \multicolumn{2}{|l|}{93} & \multicolumn{2}{|l|}{8.7} & 2 \\
\hline Total & \multicolumn{2}{|l|}{1071} & \multicolumn{2}{|c|}{100} & \\
\hline \multicolumn{6}{|c|}{ (3) Fund management, 1999iii (by institutional equity holdings, \$bn) } \\
\hline & \multicolumn{2}{|c|}{ Country } & \multicolumn{2}{|c|}{ Equity Holdings } & Global Rank \\
\hline London & \multicolumn{2}{|l|}{ UK } & \multicolumn{2}{|l|}{2461} & 1 \\
\hline Frankfurt & \multicolumn{2}{|c|}{ Germany } & \multicolumn{2}{|c|}{310} & 13 \\
\hline \multicolumn{6}{|c|}{ (4) Location of daily derivatives turnover, $2001^{\mathrm{ii}}$ (turnover, \$bn) } \\
\hline & \multicolumn{2}{|c|}{$\begin{array}{l}\text { (a) Average daily OTC } \\
\text { turnover in April }(\$ b n)\end{array}$} & \multicolumn{2}{|c|}{$\begin{array}{l}\text { (b) Annual number of } \\
\text { contracts (millions) }\end{array}$} & $\begin{array}{l}\text { Global Rank } \\
\begin{array}{ll}\text { (a) } \quad \text { (b) }\end{array}\end{array}$ \\
\hline UK & \multicolumn{2}{|c|}{275} & \multicolumn{2}{|c|}{302} & 15 \\
\hline Germany & \multicolumn{2}{|l|}{97} & \multicolumn{2}{|l|}{674} & 3 \\
\hline Totals & \multicolumn{2}{|l|}{764} & \multicolumn{2}{|c|}{4504} & \\
\hline \multicolumn{6}{|c|}{ (5) Foreign exchange dealing, $2001^{\text {ii }}$ (daily average) } \\
\hline & Value \$bn & & \% share & & Global Rank \\
\hline UK & 504 & & 31 & & 1 \\
\hline Germany & 88 & & 5 & & 5 \\
\hline Totals & 1618 & & 100 & & \\
\hline & Financial ins & itutions in LC & ndon and Fran & kfurt & \\
\hline & $\begin{array}{l}\text { Futures/ } \\
\text { derivatives } \\
\text { companies }\end{array}$ & $\begin{array}{l}\text { Forex/ } \\
\text { money } \\
\text { brokerage/ } \\
\text { discount } \\
\text { house }\end{array}$ & \begin{tabular}{|l|} 
Investment \\
and \\
(merchant) \\
banks
\end{tabular} & $\begin{array}{l}\text { Investment } \\
\text { manage- } \\
\text { ment } \\
\text { companies }\end{array}$ & $\begin{array}{l}\text { Securities/ } \\
\text { brokerage } \\
\text { companies }\end{array}$ \\
\hline London & 150 & 24 & $168(61)$ & 88 & 477 \\
\hline Frankfurt & 63 & 2 & $54(9)$ & 13 & 75 \\
\hline & Senior staf & in investmen & t banks in Lonc & don and Fran & furt, $^{\text {iv }}$ \\
\hline & Derivatives & Forex & Equities total & $\begin{array}{l}\text { Fixed } \\
\text { income total }\end{array}$ & $\begin{array}{l}\text { Mergers } \\
\text { and } \\
\text { acquisitions }\end{array}$ \\
\hline London & 376 & 532 & 1092 & 1188 & 124 \\
\hline Frankfurt & 80 & 139 & 183 & 204 & 32 \\
\hline & ) Senior staf & in investmen & t banks in Lon & don and Fran & furt, ${ }^{\text {iv }}$ \\
\hline & $\begin{array}{l}\text { Syndicated } \\
\text { lending }\end{array}$ & Other & Total & & \\
\hline London & 84 & 1641 & 5037 & & \\
\hline Frankfurt & 17 & 366 & 1021 & & \\
\hline & Number of $t$ & eign banks, & 2001 (incl. repr & esentative of & ces) $)^{v}$ \\
\hline & $\begin{array}{l}\text { Foreign } \\
\text { banks }\end{array}$ & & & & \\
\hline
\end{tabular}




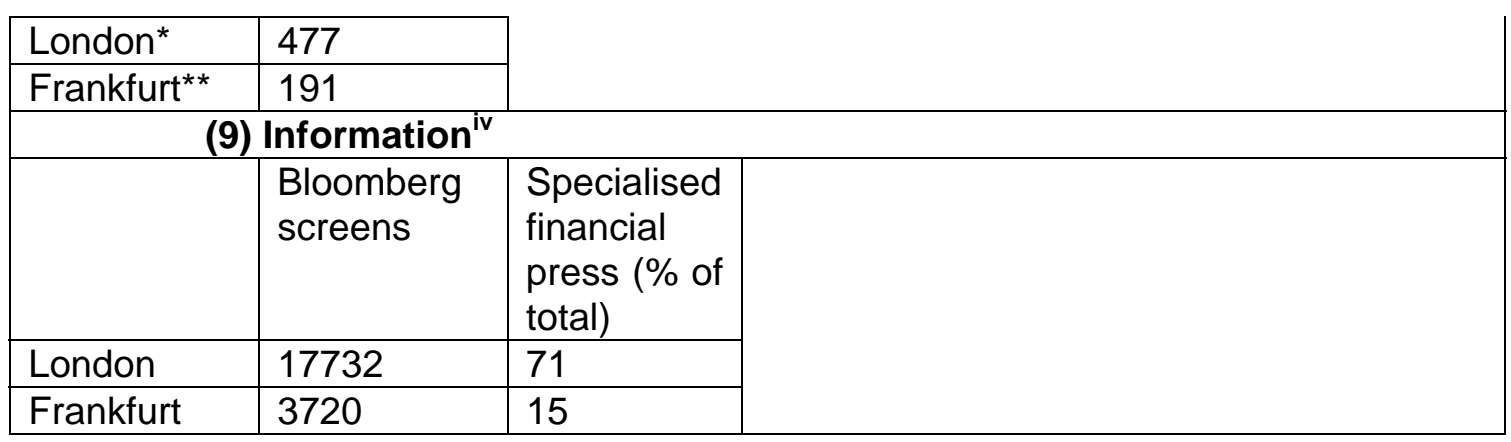

Sources:

i London Stock Exchange (quoted in International Financial Services London (IFSL) 2002).

ii Bank for International Settlements (quoted in IFSL 2002).

iii Thomson Financial Investor Relations, Target Cities Report 2000 (quoted in IFSL 2001).

iv Seifert, W.G., Achleitner, A.-K., Mattern, F., Streit, C.C., Voth, H.J. (n.d.) The performance of European financial centers - indicators and trends (http://www.palgrave.com/business/professional/fcm/, accessed 10 March 2005)

$\checkmark$ *The Bank of England (quoted in IFSL 2002); ** Deutsche Bundesbank, Hauptverwaltung Frankfurt (2002): Vierteljahreszahlen, 3. Quartal. 
Table 3. Top 15 cities for global network connectivity and banking network connectivity

\begin{tabular}{|l|c|c|l|c|c|}
\hline \multicolumn{2}{|c|}{ Global network connectivity } & \multicolumn{2}{c|}{ Banking network connectivity } \\
\hline World city & Rank & Score & $\begin{array}{l}\text { International } \\
\text { financial centre }\end{array}$ & Rank & Score \\
\hline London & 1 & 1.000 & London & 1 & 1.000 \\
New York & 2 & 0.976 & New York & 2 & 0.984 \\
Hong Kong & 3 & 0.707 & Tokyo & 3 & 0.943 \\
Paris & 4 & 0.699 & Hong Kong & 4 & 0.854 \\
Tokyo & 5 & 0.691 & Singapore & 5 & 0.804 \\
Singapore & 6 & 0.645 & Paris & 6 & 0.789 \\
Chicago & 7 & 0.616 & Frankfurt & 7 & 0.698 \\
Milan & 8 & 0.604 & Madrid & 8 & 0.686 \\
Los Angeles & 9 & 0.600 & Jakarta & 9 & 0.662 \\
Toronto & 10 & 0.595 & Chicago & 10 & 0.650 \\
Madrid & 11 & 0.594 & Milan & 11 & 0.633 \\
Amsterdam & 12 & 0.590 & Sydney & 12 & 0.625 \\
Sydney & 13 & 0.578 & Los Angeles & 13 & 0.617 \\
Frankfurt & 14 & 0.567 & Mumbai & 14 & 0.616 \\
Brussels & 15 & 0.557 & San Francisco & 15 & 0.614 \\
\hline
\end{tabular}

Source: Taylor and Catalano (2002). 